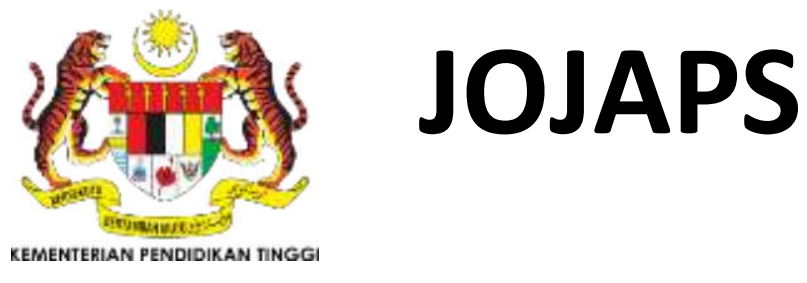

eISSN 2504-8457

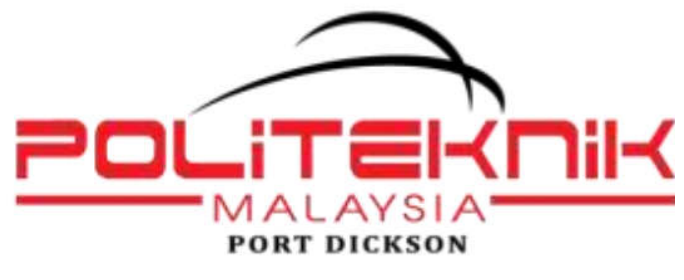

Journal Online Jaringan Pengajian Seni Bina (JOJAPS)

\title{
Influence of Celebrity Endorser Raisa Andriana in Advertisement on Magnum Ice Cream Brand Image on the Transmart Costumers
}

\author{
Ruri Sabdillah ${ }^{1}$, Rahmat Hidayat ${ }^{2 *}$, Dewi Shinta Wulandari Lubis ${ }^{3}$, Wardayani ${ }^{4}$ \\ ${ }^{1,2,3,4}$ Departement of Management, STIM Sukma Medan, Indonesia \\ *rhidayat@stimsukmamedan.ac.id
}

\begin{abstract}
This study is aimed to determine the effect of Raisa Adriana celebrity endorser in Magnum ice cream brand image advertising on the consumer of Transmart Carrefour Plaza Medan Fair. The study was conducted at Transmart Carrefour Plaza Medan Fair in 2016. The data used in this study was primary data in the form of interviews and questionnaires which distributed to the 138 research respondents. The data were analyzed by simple regression where the hypothesis was tested by using the coefficient of determination and partial test. Moreover, the data was processed by SPSS application. The results showed that the celebrity endorser Raisa Adriana have a positive and significant effect to brand image of Magnum ice cream at Transmart Carrefour Plaza Medan Fair customers.
\end{abstract}

(C) 2017 Published by JOJAPS Limited.

Keywords: Celebrity endorser, brand image, advertisement

\section{Background}

It has been a trend that the public figures such as model, singer, famous athletes, and actress were invited to be the advertisement model for magazine, television, and social media. On of the advertisement is the Magnum Ice cream which uses Raisa Adriana as the celebrity endorser. As a celebrity, Raisa is known very well on the society and has positive image in case she has never been reported for bad gossip or bad news. The celebrity will explain the product she endorses in order to influence the perception of the consumers in making the decision to buy the product. By the endorsement of Raisa Adriana, it is fully beleived that the product sale will be increased and the positive brand image will be achieved. For instance, the research result of Cholifah et el (2016) showed that several variables on celebrity endorsement such as trustworthiness, expertise, attractiveness, respect, and similarity have very significant effect on the brand image. Moreover, the research result of Wang et el (2017) also showed that there is a positive relationship among all the hypothesis constructed. Therefore, besides having a good celebrity in supporting the costumer oriented endorsement, the celebrity credibility is also as important as the brand character achievement, brand credibility, and the purchasing willingness. Moreover, the price determination and promotion also influence the sale rate.

\section{Literature review}

Kertamuki (2015: 69) stated that celebrity endorser is a famous individual on society by his or her achievement on art beside the products he or she endorses. Moroevoer, Kertamkukti (2015: 75) stated that there are basic supporting properties which support the endorsing effectiveness, they are: (1) attractiveness which consists of: familiarity, similarity, and liking, (2) credibility which consists of: expertise and trustworthiness. In addition, Kotler and Keller (2009: 260) defined that brand image is a process where the costumers selects, organizes, and defines the input information to create a thoughful image. Thus, Kotler and Keller (2009) stated that there are brand image indicator; favorability of brand association, strength of brand association/ familiarity of brand association and uniqueness of brand association. 


\section{Research methods}

The research was conducted at Transmart Carrefour Plaza Medan Fair on 2016. The variables on the research were two: celebrity Endorser Raisa Adriana as the exogen variable and the Magnum Ice cream brand image as the endogen variable. The data that used on the research were two, they are the primary data: interview and questionnaire sheets that were distributed to the 138 research respondents. The data was tested by simple regression test. Meanwhile, the hypothesis was tested by determination coefficient test and partial test, last, the data was analyzed through SPSS application.

\section{Result}

\section{Respondent Characteristics}

Table 1. Respondent Identities by gender

\begin{tabular}{llrr}
\hline No. & Sex & Responden & Percentage \\
\hline 1 & Male & 60 & 43.48 \\
2 & Female & 78 & 56.52 \\
\hline Total & & 138 & 100.00 \\
\hline
\end{tabular}

Table 2. Respondent Identities by age

\begin{tabular}{clcc}
\hline No. & Age range & Respondent Number & Percentage \\
\hline 1 & $17-20$ Tahun & 56 & 40.58 \\
2 & $21-25$ Tahun & 82 & 59.42 \\
\hline Total & & 138 & 100.00 \\
\hline
\end{tabular}

2. The recapitulation of respondents' respond on the celebrity endorser variable

Table 3. The recapitulation of respondents' respond on the celebrity endorser variable

\begin{tabular}{|c|c|c|c|c|c|c|c|c|c|c|c|c|}
\hline \multirow[t]{2}{*}{ No } & \multirow[t]{2}{*}{ Statements } & \multicolumn{2}{|c|}{ Very agree } & \multicolumn{2}{|c|}{ Agree } & \multicolumn{2}{|c|}{ Less agree } & \multicolumn{2}{|c|}{ disagree } & \multicolumn{2}{|c|}{$\begin{array}{c}\text { Very } \\
\text { disagree }\end{array}$} & \multirow[t]{2}{*}{ Total } \\
\hline & & $\mathrm{F}$ & $\%$ & $\mathrm{~F}$ & $\%$ & $\bar{F}$ & $\%$ & $\mathrm{~F}$ & $\%$ & $\bar{F}$ & $\%$ & \\
\hline 1 & $\begin{array}{l}\text { Do you know Raisa (pop } \\
\text { singer) }\end{array}$ & 29 & 21 & 70 & 51 & 39 & 28 & 0 & 0 & 0 & 0 & 138 \\
\hline 2 & $\begin{array}{l}\text { seldom/ ever watched Raisa at } \\
\text { electronic media }\end{array}$ & 15 & 11 & 69 & 50 & 38 & 28 & 13 & 9 & 3 & 2 & 138 \\
\hline 3 & Is Raisa appearance elegant? & 22 & 16 & 69 & 50 & 42 & 30 & 4 & 3 & 1 & 1 & 138 \\
\hline 4 & $\begin{array}{l}\text { Do you like Magnum Ice } \\
\text { Cream just like Raisa? }\end{array}$ & 19 & 14 & 74 & 54 & 39 & 28 & 6 & 4 & 0 & 0 & 138 \\
\hline 5 & $\begin{array}{l}\text { Raisa is an actrees which less } \\
\text { gossiped? }\end{array}$ & 23 & 17 & 70 & 51 & 43 & 31 & 1 & 1 & 1 & 1 & 138 \\
\hline 6 & I love Raisa performance & 15 & 11 & 69 & 50 & 45 & 33 & 7 & 5 & 2 & 1 & 138 \\
\hline 7 & $\begin{array}{l}\text { Raisa endorses the } \\
\text { advertisement very well }\end{array}$ & 24 & 17 & 79 & 57 & 34 & 25 & 0 & 0 & 1 & 1 & 138 \\
\hline 8 & $\begin{array}{l}\text { The message of advertisement } \\
\text { is delivered very well }\end{array}$ & 21 & 15 & 77 & 56 & 30 & 22 & 3 & 2 & 7 & 5 & 138 \\
\hline 9 & $\begin{array}{l}\text { The message of advertisement } \\
\text { delivered can be trusted }\end{array}$ & 14 & 10 & 79 & 57 & 36 & 26 & 8 & 6 & 1 & 1 & 138 \\
\hline 10 & $\begin{array}{l}\text { Raisa has very good self } \\
\text { image }\end{array}$ & 14 & 10 & 64 & 46 & 54 & 39 & 5 & 4 & 1 & 1 & 138 \\
\hline & Average & & 14 & & 52 & & 29 & & 3 & & 1 & \\
\hline
\end{tabular}


3. The recapitulation of respondents' responds on brand image variable

Table 4. The recapitulation of respondents' responds on brand image variable

\begin{tabular}{|c|c|c|c|c|c|c|c|c|c|c|c|c|}
\hline \multirow[t]{2}{*}{ No } & \multirow[t]{2}{*}{ Statements } & \multicolumn{2}{|c|}{$\begin{array}{l}\text { Very } \\
\text { Agree }\end{array}$} & \multicolumn{2}{|c|}{ Agree } & \multicolumn{2}{|c|}{ Less Agree } & \multicolumn{2}{|c|}{ Disagree } & \multicolumn{2}{|c|}{$\begin{array}{c}\text { Very } \\
\text { Disagree }\end{array}$} & \multirow[t]{2}{*}{ Total } \\
\hline & & $\mathrm{F}$ & $\%$ & $\mathrm{~F}$ & $\%$ & $\mathrm{~F}$ & $\%$ & $\mathrm{~F}$ & $\%$ & $\mathrm{~F}$ & $\%$ & \\
\hline 1 & $\begin{array}{l}\text { The Magnum ice cream brand } \\
\text { is a brand that loved by the } \\
\text { costumers }\end{array}$ & 54 & 39 & 58 & 42 & 21 & 15 & 5 & 4 & 0 & 0 & 138 \\
\hline 2 & $\begin{array}{l}\text { Magnum brand can influence } \\
\text { the costumers to buy the } \\
\text { Magnum ice cream }\end{array}$ & 33 & 24 & 69 & 50 & 24 & 17 & 7 & 5 & 5 & 4 & 138 \\
\hline 3 & $\begin{array}{l}\text { Magnum ice cream brand is a } \\
\text { famous brand in Indonesia }\end{array}$ & 28 & 20 & 76 & 55 & 32 & 23 & 0 & 0 & 2 & 1 & 138 \\
\hline 4 & $\begin{array}{l}\text { Magnum ice cream brand can } \\
\text { improve the brand image of } \\
\text { the product }\end{array}$ & 33 & 24 & 71 & 51 & 28 & 20 & 5 & 4 & 1 & 1 & 138 \\
\hline 5 & $\begin{array}{l}\text { Magnum ice cream brand has } \\
\text { very unique variants of ice } \\
\text { cream }\end{array}$ & 47 & 34 & 61 & 44 & 21 & 15 & 7 & 5 & 2 & 1 & 138 \\
\hline 6 & $\begin{array}{l}\text { The variant of Magnum ice } \\
\text { cream has the unique wrapper }\end{array}$ & 38 & 28 & 68 & 49 & 24 & 17 & 7 & 5 & 1 & 1 & 138 \\
\hline & Average & & 28 & & 49 & & 18 & & 4 & & 1 & \\
\hline
\end{tabular}

\section{Regression test result}

Table 5. Regression test result

\begin{tabular}{|c|c|c|c|c|c|}
\hline \multirow{3}{*}{ Model } & \multicolumn{3}{|c|}{ Coefficients $^{\mathrm{a}}$} & \multirow{3}{*}{$\mathrm{t}$} & \multirow{3}{*}{ Sig. } \\
\hline & \multicolumn{2}{|c|}{$\begin{array}{c}\text { Unstandardized } \\
\text { Coefficients }\end{array}$} & \multirow{2}{*}{$\begin{array}{c}\text { Standardized } \\
\text { Coefficients } \\
\text { Beta }\end{array}$} & & \\
\hline & $\mathrm{B}$ & Std. Error & & & \\
\hline (Constant) & 19.010 & 2.396 & & 7.934 & .000 \\
\hline Celebrity endorser $(\mathrm{x})$ & .131 & .064 & .174 & 2.060 & .041 \\
\hline a. Dependent Variable: Brar & $\operatorname{ge}(\mathrm{y})$ & & & & \\
\hline
\end{tabular}

By the table above, the results show that there is a regression equation: $\mathrm{Y}=19.010+0.131 \mathrm{X}$

On the regression model, it can be gotten the constant score is 19.010 which means if the celebrity endorsement variable scor is zero so the brand image variable scor is 19.010 . The regression coefficiency the brand image variable has positive value, which proves its contribution. It means that Magnum ice cream brand image can be influenced by Raisa Adriana celebrity endorsement.

\section{Hypothesis testing}

1. Determination coefficiency $\left(\mathrm{R}^{2}\right)$

Table 6. The result of determination coefficiency

\begin{tabular}{|c|c|c|c|c|}
\hline \multicolumn{5}{|c|}{ Model Summary } \\
\hline Model & $\mathrm{R}$ & R Square & $\begin{array}{l}\text { Adjusted R } \\
\text { Square }\end{array}$ & $\begin{array}{l}\text { Std. Error of the } \\
\text { Estimate }\end{array}$ \\
\hline 1 & $.174^{\mathrm{a}}$ & .030 & .023 & 3.30613 \\
\hline a. Pred & Consta & at), Celebrity & ndorser (x) & \\
\hline
\end{tabular}

The table above showed that the value of $\mathrm{R}^{2}$ is 0.030 or $3 \%$, which means the celebrity endorses power in explaining the brand image is $3 \%$ meanwhile the rest the other $97 \%$ is explained by other variables that not explained at this research (further research needs to be conducted). 
2. Partial test ( $\mathrm{t}$ test)

Table 7. Partial test result

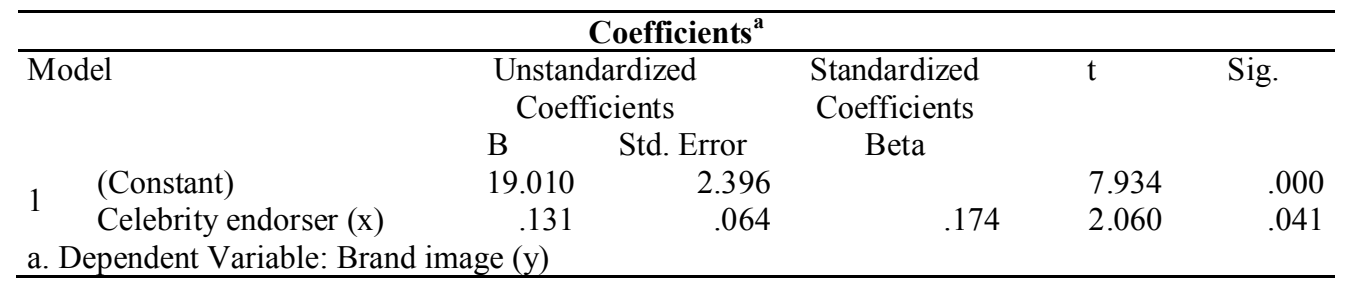

The table above showed that the $t_{\text {count }}$ for the celebrity endorser variable is 2.060 times bigger from $t_{\text {table }} 1.977$ and the significancy value is 0.041 smaller than alpha 0.05 , so $\mathrm{H}_{0}$ is rejected and $\mathrm{H}_{1}$ is accepted. Thus, the Raisa Adriana celebrity endorser has positive significant effect on Magnum ice cream brand image on Transmart Carrefour Plaza Medan Fair costumers. The results is same whith the research of Cholifah et el (2016) which stated that the variables on the celebrity endorser which consists of trustworthiness, expertise, attractiveness, respect, and similarity have significant effect to the brand image. The result is also same with Wang et. el (2017) research that there is positive relationship between all the construction hypothesized. Therefore, besides having a good celebrity to support the costumer oriented advertisement, the celebrity credibility is as important as brand image in improving the brand characteristic, brand credibility and buying willingness. Nevertheless, the research of Ilicic \& Webster (2013) stated that co branding celebrity client does not give the information about the client brand or brand profit, the costumers' judgment to the brand client capability on giving the benefits, buying willingness, and suitable perception will become negative.

The other statement by Kim et el (2014) stated that the trustworthiness on the celebrity endorsement by costumers can be changed with image perception, credibility, and loyalty to the costumers. One important investigation result showed that specific celebrity endorsers might be uninteresting for the whole market target, but more than one endorser might be asked to promote the product. Meanwhile, Wei \& Lu (2013) stated that a good search of good product that is suggested by a celebrity in an advertisement is by making the attention, willingness, and more action from costumer's rather that do a survey to the costumers on online version. Moreover, the research also showed that online costumers are more active than the support of the celebrity to the respondent memories. In addition, Lubis \& Hidayat (2017) also stated that the brand image does not influence the buying decision, meanwhile the price is positively and significantly influence the buying decision. Last, simultaneously the brand image and the price influence positively and significantly to the buying decision.

\section{Reference}

Batubara, A., \& Hidayat, R. (2016). Pengaruh Penetapan Harga dan Promosi terhadap Tingkat Penjualan Tiket pada PSA Mihin Lanka Airlines. Jurnal Ilman, 4(1), 33-46.

Cholifah, N., Suharyono, \& Hidayat, K. (2016). Pengaruh Celebrity Endorser terhadap Brand Image (Survei pada Konsumen Kosmetik Wardah di Counter Wardah Kota Malang). Jurnal Administrasi Bisnis (JAB), 36(1), 170-177.

Ilicic, J., \& Webster, C. M. (2013). Celebrity co-branding partners as irrelevant brand information in advertisements. Journal of Business Research, 66(7), 941-947. https://doi.org/http://dx.doi.org/10.1016/j.jbusres.2011.12.014

Kertamukti, R. (2015). Strategi Ktreatif dalam Periklanan Konsep Pesan, Media, Branding, Anggaran (1st ed.). Jakarta: PT. Raja Grafindo Persada.

Kim, S. S., Lee, J., \& Prideaux, B. (2014). Effect of celebrity endorsement on tourists' perception of corporate image, corporate credibility and corporate loyalty. International Journal of Hospitality Management, 37, 131-145.

Kotler, P., \& Keller, K. L. (2009). Manajemen Pemasaran (13th ed.). Jakarta: Erlangga.

Lubis, D. I. D., \& Hidayat, R. (2017). Pengaruh Citra Merek dan Harga terhadap Keputusan Pembelian pada Sekolah Tinggi Ilmu Manajemen Sukma Medan. Jurnal Ilman, 5(1), 15-24.

Wang, S. W., Kao, G. H.-Y., \& Ngamsiriudom, W. (2017). Consumers' attitude of endorser credibility, brand and intention with respect to celebrity endorsement of the airline sector. Journal of Air Transport Management, 60, 10-17.

Wei, P.-S., \& Lu, H.-P. (2013). An examination of the celebrity endorsements and online customer reviews influence female consumers' shopping behavior. Computers in Human Behavior, 29(1), $193-201$. https://doi.org/http://dx.doi.org/10.1016/j.chb.2012.08.005 